\title{
FAR TOO MANY WOMEN? JOHN GRAUNT, THE SEX RATIO, AND THE CULTURAL DETERMINATION OF NUMBER IN SEVENTEENTH-CENTURY ENGLAND*
}

\author{
MARGARET PELLING \\ University of Oxford
}

\begin{abstract}
A B S T R A CT. John Graunt's analysis of the London Bills of Mortality of I 662 is famous as a pioneering contribution to the study of human populations. But comparatively little attention has been given to his highly influential discovery that the numbers of men and women were evenly balanced. Why did Graunt think that what we now call the sex ratio was important, and why did he see it as essential to contradict received opinion? What can we deduce about Graunt's own attitudes to women? Why was he concerned to discredit polygamy? Further investigation suggests, not that Graunt shared the misogyny of many of his contemporaries, but that he was motivated by the dangers inherent in his own shifting religious views, which included Socinianism and antiTrinitarianism. The religious controversialist Bernardino Ochino can be detected as a dark influence behind Graunt's thinking. An exploration of Graunt's cultural hinterland confirms that men did indeed believe that they were outnumbered by women, a conviction accentuated by the unnerving upheavals of religious conflict, plague, and civil war, and apparently confirmed by prophecy. Seventeenth-century misogyny seems to present itself to us as qualitative, but it included a numerical dimension which was in effect culturally determined.
\end{abstract}

In 1662, John Graunt, citizen, haberdasher, and Draper of London, published the first edition of his Natural and political observations... upon the Bills of Mortality. This work had considerable impact and reached five editions by 1676 . Graunt

Wellcome Unit for the History of Medicine, Oxford, OX2 6PE Margaret.pelling@history.ox.ac.uk

* The first version of this article was given at a conference on gender and health organized by Sarah Toulalan at Exeter in 2008. I am grateful to her and to the audience there for their comments, as also to the audience who heard a much-revised version in Oxford in 2012, and to two anonymous referees of this journal. I owe thanks in addition to Erica Charters, Eddy Higgs, Joanna Innes, Lauren Kassell, Claas Kirchhelle, Anne Laurence, Rhodri Lewis, Diarmaid MacCulloch, Ross McKibbin, and Stephen Thompson. Particular thanks are due to Vanessa Harding, Paul Slack, Charles Webster, and Philip Kreager who kindly commented on the final version and provided me with copies of his latest work on Graunt.

695 
has subsequently achieved a unique status as a pioneer in the use of number for socio-political purposes and, in particular, as initiating sophisticated practices to do with 'numbering the people'. The present article was prompted not by the bulk of Graunt's achievement as recognized today by historical demographers and statisticians, but by curiosity about the cultural hinterland implied by one of his stated concerns. ${ }^{1}$ In chapter XI of the Observations, Graunt discusses the number of inhabitants in London, pointing out that most men persisted in believing that these amounted to as many as two million - 'as they do, that there be three Women for one Man, whereas there are fourteen Men for thirteen Women, as elsewhere hath been said [i.e. by Graunt, earlier in the Observations]'.2 Graunt provides no evidence for, or illustrations of, this remark about the perceived excess of women, nor does he attribute it to particular individuals or groups. He presents it simply as a statement about contemporary opinion which he would expect to be recognized by all as obvious and correct. It was repeated by William Petty in his unpublished 'Treatise of Ireland', presented to James II in 1687. Petty, however, attributed a lesser degree of error to his contemporaries: 'tho' the World thought there had been near twice as many Females as Males in Mankind; yet it has been well proved that there are at London 14 Males to 13 Females, and at Rome 7 to 5'.3 Petty's later assertion is useful in suggesting that the notion that women dominated over men numerically was not confined to London or to Londoners. So did 'the World' really think this about women, and if so, why?

\section{I}

Not surprisingly, Graunt's work has not been seen as a relevant text by historians of women or of gender, and his claim as to contemporary opinion about excess women has not been taken up or explored. ${ }^{4}$ C. H. Hull, whose edition of Petty's work and of the Observations is still essential reading, gives contemporary sources for the equally mistaken views that Graunt cites on the size of London's population, but provides none for the statement about excess women. Yet Graunt's statement is a remarkable one, and its implications are considerable and various. As I hope to show, many of these connect with religious, political,

${ }^{1}$ For an invaluable reassessment of the afterlife of Graunt's work, see P. Kreager, 'Histories of demography: a review article', Population Studies, 47 (1993), pp. 519-39.

${ }^{2}$ C. H. Hull, ed., The economic writings of Sir William Petty together with the Observations upon the Bills of Mortality more probably by Captain John Graunt (2 vols., 1899; repr. New York, NY, 1963-4), II, pp. $3^{8} 5^{-6}$ (n.b. Hull's footnote, p. $3^{8} 5$ ). Hull reprints the $5^{\text {th }}$ edition $\left({ }_{1676)}\right.$, and this edition will be quoted unless otherwise stated. For present purposes, the $5^{\text {th }}$ edition is not materially different from the 1 st edition of 1662 (see ibid., II, pp. $3^{1} 7^{-18}$ ).

3 Ibid., II, pp. 546, 603.

4 See for example R. Thompson, 'Seventeenth-century English and colonial sex ratios: a postscript', Population Studies, 28 (1974), pp. 153-65, at p. $16_{4}$. One of the few to take some note is A. M. Endres, 'The functions of numerical data in the writings of Graunt, Petty and Davenant', History of Political Economy, 17 (1985), pp. $245^{-64}$, at pp. $24^{8-9}$. 
and cultural concerns not normally associated with Graunt. The Observations, with its dedication to the president of the Royal Society, Sir Robert Moray, has usually been seen as an exercise in Baconian self-discipline, characterized by plain prose and an empirical methodology. Graunt himself claimed to be prompted by 'finding some Truths, and not commonly-believed Opinions' during his first 'meditations' on the Bills. Later commentators, like Sir Peter Pett, praised his 'solid and rational calculations'.5 Statements in the Observations of broader or more speculative import, especially in relation to politics and government, have tended to be ascribed to William Petty, once identified as the author of the work and still regarded by many as a contributor. Unlike his vastly more prolific and well-connected friend Petty, Graunt has not been credited with much subjectivity, partly because the Observations is the only extant work that can be ascribed to him, partly because comparatively little is known of his life, and partly because of his persona, which he himself helped to construct, as an upper tradesman of plain views and modest ambition.

Yet some of what is known about Graunt is, or should be, suggestive of a complex if not tormented inner life. He died in 1674 , having lived through the turbulence of the Civil Wars as a young man. Being 'puritanically bred' according to Anthony Wood, he then had to adjust to the Restoration, as well as suffering major losses in the Great Fire. Perhaps most significantly, he was said to have made what must have been a painful journey from Socinianism to Roman Catholicism, a transition which arguably led to adverse effects on his posthumous reputation. As a member of the New River Company, he was later accused, with no justification, of complicity in the Fire. Ultimately, contemporaries were prepared to adopt his findings while blackening the name and reputation of their author. This probably inclined some to ascribe his work to Petty, who was himself alienated by Graunt's change of religious allegiance. ${ }^{6}$ Graunt is therefore inseparable both from the theological upheavals of the

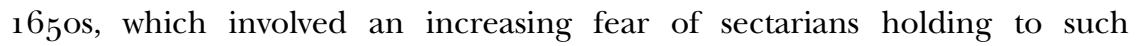
extreme notions as mortalism and anti-Trinitarianism, and from the aftermath of these upheavals in the Restoration.7

The complexities of Graunt's life and of its context should prompt us to look more closely at the motivations behind his unique achievements. Why, for example, did Graunt include the sex ratio (not of course a term he used) in

5 Graunt, Observations, ed. Hull, II, pp. $3^{8} 3,3^{8} 5^{-6}$, 334; Pett quoted in ibid., I, p. xliv. For Graunt's method in its Baconian and mercantile context, see P. Kreager, 'New light on Graunt', Population Studies, 42 (1988), pp. 129-40; P. Kreager, 'Death and method: the rhetorical space of seventeenth-century vital measurement', in E. Magnello and A. Hardy, eds., The road to medical statistics (Clio Medica No. 67, Amsterdam, 2002), pp. 1-35.

6 On Graunt's life, see Graunt, Observations, ed. Hull, I, pp. xxxiv-viii, xli, xlv; C. G. Lewin, 'Graunt, John (1620-1674)', Oxford dictionary of national biography (ODNB); D. V. Glass, 'John Graunt and his Natural and political observations', Notes and Records of the Royal Society, 19 (1964), pp. 63-10o.

7 Sarah Mortimer, Reason and religion in the English revolution: the challenge of Socinianism (Cambridge, 2010), esp. pp. 218-20. 
what was primarily a refutation of common errors, mainly about population, and a reassessment of risk factors, such as the most likely causes of death? How visible are women in his overall discussion? Can Graunt be found to have a set of attitudes to women? Here, the most obvious and important connection - though Graunt hardly dwells on it - is with his remarks about polygamy. Why did he raise this subject at all, and why should polygamy be a particular practical concern to a society in which it was not practised? Historians usually see debates about polygamy as belonging to a later period. What evidence can we find to confirm that contemporaries thought about women as Graunt claimed they did? If it was thought that there was an excess of women, why did this view take on such strength that Graunt saw the need to combat it in an analysis of London's population? Why was his success in this respect so welcome to his contemporaries and later readers alike? This article will seek to make deductions about Graunt's inner life, but also, and more demonstrably, to explore how his brief but telling comments fit into mid-century opinion and attitudes to women. This will add another, but more literal, dimension to the well-established issue of women's visibility - or lack of it - at this period. It will also suggest much about how number was used as a cultural tool in early modern English society.

Graunt's discovery that the sex ratio was more or less equal was confirmed by Petty, and enthusiastically welcomed by Protestant providentialists, such as William Derham, who were also comforted by Graunt's finding that nature provided, if anything, a slight excess of males. That the world - the Protestant world at least - was based on one woman for each man seemed to provide a direct link with Genesis and with God's plan for his chosen people. In the modern period, Graunt's achievement has been widely acknowledged by historical demographers, although the unavoidable imperfections of his data meant that credit has also been given to later calculations, notably those by Gregory King. Glass calls the sex ratio Graunt's 'best-known contribution' and one that led to an 'intellectual chain-reaction', while finding it 'less stimulating' himself. It may therefore seem strange that such limited attention has been given to why Graunt was interested in the sex ratio in the first place. One reason for this may be that there often appears to be little in common between historians likely to comment on sex ratios, and those primarily interested in gender relations. One major exception is Peter Biller, who, in writing illuminatingly about the medieval period, points to historians' failure to bring together the 'notions' and the 'numbers'. ${ }^{8}$ Yet, as other historians have pointed out, 'notions' - social and cultural beliefs or perceptions influencing behaviour-are crucial to

8 J. Bonar, Theories of population from Raleigh to Arthur Young (London, 1931), p. 133; Thompson, 'Seventeenth-century English and colonial sex ratios', p. 161; Glass, 'John Graunt', pp. 77, 87; Kreager, 'New light on Graunt', p. 140; P. Biller, The measure of multitude: population in medieval thought (Oxford, 200o), p. 89. On King, see esp. C. Brooks, 'Projecting, political arithmetic and the Act of 1695', English Historical Review, 97 (1982), pp. 31-53. 
demographic change, and attitudes to women, as well as the views of women themselves, must be included among these. 9

The divide between notions and numbers is partly attributable to the fact that commentary on women in the early modern period seems on the face of it to be overwhelmingly in qualitative terms. The misogynistic diatribes of the early Stuart period, for example, or the vitriolic attacks on old maids escalating later in the century, are so uninhibited in their critiques of woman's nature that there seems little need to look further. These published sources deal in qualities, not quantities. By contrast, what we know about early modern sex ratios has had to be reconstructed retrospectively, in terms of quantities, or the 'real'. There has been some speculation, notably in the work by Guttentag and Secord, about what the possible effects of an actual unbalanced ratio might have been. ${ }^{10}$ In general, for such purposes, it is tacitly assumed that contemporaries knew what their sex ratio was and responded accordingly. It is part of the argument here to suggest that this assumption is open to question. Can we really link demographic regimes directly with human behaviour, as if anyone might readily perceive what kind of demographic regime they were living in? Can we further assume that such perceptions would be accurate? In the context being considered here, this would involve assuming that contemporaries could, on the basis of everyday observation, make an objective assessment of whether the sex ratio was balanced or not-and this in a society which on the one hand over-reacted to even small gatherings of women, and at the same time sought to ensure that women remained within the household and were as invisible as possible. It should be stressed that we will not be concerned here with the 'real numbers' or their possible consequences as we might reconstruct them, which have been dealt with imaginatively in the survey by Guttentag and Secord, and for London by Finlay and others. Rather, the concern is with number as an aspect of contemporary culture and belief. However, the argument does have implications for the nature of demographic perception. ${ }^{11}$

9 See for example Nancy Birdsall, 'Women and population studies', Signs, 1 (1976), pp. 699-712; Bridget Hill, 'The marriage age of women and the demographers', History Workshop Journal, 28 (1989), pp. 129-47; Anne-Lise Head-König, 'Demographic history and its perception of women from the seventeenth to the nineteenth century', in K. Offen, R. R. Pierson, and J. Randall, eds., Writing women's history: international perspectives (Basingstoke, 1991), pp. $25^{-44}$.

10 Marcia Guttentag and P.F. Secord, Too many women? The sex ratio question (Beverly Hills, CA, 1983); R. Finlay, Population and metropolis: the demography of London, $1580-1650$ (Cambridge, 1981), pp. 130-1, 140-2; J. Boulton, Neighbourhood and society: a London suburb in the seventeenth century (Cambridge, 1987), p. 130; J. Landers, Death and the metropolis: studies in the demographic history of London, I670-1830 (Cambridge, 1993); V. Harding, 'The population of London, 1550-1700: a review of the published evidence', London Journal, 15 (1990), pp. $111-28$.

${ }_{11}$ Guttentag and Secord, Too many women; T. Dyson, 'Causes and consequences of skewed sex ratios', Annual Review of Sociology, $3^{8}$ (2012), pp. 443-61; Sara Mendelson and Patricia Crawford, Women in early modern England (Oxford, 1998), p. 168. See also, most recently, 
The starting point must be the Observations itself, which is effectively the only evidence for Graunt's views. He communicated other sorts of observations to the Royal Society, and wrote other works (on the excise, and, intriguingly, 'something about religion') which do not survive. The Observations was popular enough to be plagiarized, and this work, and another, A defence of Christian liberty (1646), have been ascribed to him, but it seems clear that the Observations was his only publication. ${ }^{12}$ Much more pervasive has been the claim that William Petty either wrote the Observations or had a major hand in it. Partly, as already indicated, this has rested on contemporary distaste for Graunt as opposed to his findings, while Petty seems increasingly to have been willing to take as much credit as was offered. Later commentators have favoured Petty because he was a 'player' and Graunt was not. On balance, however, Graunt's overall authorship is now accepted, and the input most recently claimed by some for Petty relates to passages not relevant to the present discussion. ${ }^{13}$ Petty himself attributed the correcting of the sex ratio to the Observations, if not to Graunt by name. ${ }^{14}$ In terms of reconstructing the climate of contemporary opinion, it need not matter whether we are dealing with the words of Petty or the words of Graunt. However, as already suggested, it seems mistaken to ascribe all sentiments of a socio-political nature to Petty, let alone those with religious connections. Graunt was an articulate and cultivated man, 'who understood Latin and French', and who impressed Samuel Pepys with his collection of prints and drawings. The lawyer Richard Smyth remembered him as 'an understanding man, of a quick witt and a pretty schollar'. It should therefore not be surprising to find an Aristotelian echo in his use of 'natural and political' for the title of his work, or to see some link between his work and the contemporary preoccupation with 'pseudodoxia' - notions commonly but wrongly held, which under the stress of religious change had become a more acute problem, 'the distractions of men in opinions'. ${ }^{15}$

Sandy Bardsley, 'Missing women: sex ratios in England, 1000-1 500', Journal of British Studies, 53 (2014), pp. 273-309.

12 Graunt, Observations, ed. Hull, I, p. li, II, pp. 320, 432, 66o; Anon., Reflections on the weekly Bills of Mortality for the cities of London and Westminster (London, 1665); John Graunt [of Bucklersbury], A defence of Christian liberty to the Lords table (London, 1646).

13 For a full and balanced assessment, see Glass, 'John Graunt', pp. 78-89. Hull suggested that the epistle to Moray might be by Petty (Graunt, Observations, ed. Hull, I, p. lii), and others have read the Conclusions as unlikely to be by Graunt (e.g. E. Strauss, Sir William Petty: portrait of a genius (London, 1954), pp. 188-92; see esp. p. 189). But see P. Kreager, 'Graunt, John', in K. Kempf-Leonard, ed., Encyclopedia of social measurement (3 vols., San Diego, 2005), II, pp. 161-6, at p. 166.

${ }^{14}$ Graunt, Observations, ed. Hull, II, pp. 483, 6o3; Glass, 'John Graunt', pp. 79-80, 87.

${ }^{15}$ J. Aubrey, Aubrey's Brief lives, ed. O. L. Dick (Harmondsworth, 1972), p. 274; Glass, 'John Graunt'; Kreager, 'New light on Graunt'; H. Ellis, ed., The obituary of Richard Smyth (Camden Society, London, 1849), p. 102; P. Kreager, 'Aristotle and open population thinking', Population and Development Review, 34 (2008), pp. 599-629, esp. pp. 623-4; John Carpenter, 
What Graunt has to say about women in the Observations is occasionally dismissive, but is singularly lacking in the attention-seeking and often hostile tone so readily found elsewhere during his lifetime. His commentary may be divided into two kinds, the incidental and the systematic. The former includes brief remarks about lack of occupation among women and children, 'common' women and venereal disease, and the carelessness of wetnurses, whom he calls milch-women. He makes more extended mention of women's diseases, including the much-ventilated topic of greensickness and its cure by marriage, and writes, as any father of a family might do, of how he 'remembered' that some women, troubled with the mother-fits, complained of a choking in the throat. ${ }^{16}$ His interest here is in arriving at broad (and reliable) categories of disease classification, with a view to making a true estimate of the major causes of death. Elsewhere, pursuing his interest in the factors affecting generation, he refers to the barrenness of prostitutes, which was very much a classical trope, along with the related topic of levels of fertility and sexual activity among lower animals. ${ }^{17}$ Some earlier literature had made a pretence of using numerical data in aspersions on the sexual voracity of women as compared with animals, asserting for example that while one cock could satisfy fifteen hens, fifteen men might be insufficient to satisfy one woman. ${ }^{18}$ Graunt's tone and intentions are markedly different from this.

Perhaps the most important, and best-known, of Graunt's incidental references to women relate to the searchers, the ancient matrons sworn to their office, who collected information on who died from what in their parishes and reported it to the parish clerks. The Bills of Mortality were, by definition, entirely dependent upon what the searchers reported. Although Graunt is often seen as condemning the searchers, his comments are surprisingly gender-neutral. ${ }^{19}$ Although he says the searchers are 'perhaps ignorant and careless', he estimates their worth in the same manner as he might have done that of elderly men similarly recruited from the lowliest levels of parochial communities. Rather than dismissing the searchers simply because they were female, he attributes to them a standard of common-sense observation which could be expected to be universal and which was adequate for a broad categorization of diseases. Graunt's most disparaging remark about the searchers, as 'Old-women' who arrived at their diagnoses 'after the mist of a Cup of Ale,

\footnotetext{
A preparative to contentation: conteining a display of the wonderfull distractions of men in opinions and straunge conceits (London, 1597).

${ }^{16}$ Graunt, Observations, ed. Hull, II, pp. 396, 355, 352, 358, 359 .

17 Ibid., II, pp. 373, 375; Biller, Measure of multitude, pp. 101-2; Mendelson and Crawford, Women in early modern England, p. 28.

${ }^{18}$ Naomi J. Miller, "'Hens should be served first": prioritizing maternal production in the early modern pamphlet debate', in C. Malcolmson and M. Suzuki, eds., Debating gender in early modern England, I5OO-I 700 (Houndmills, 2002), pp. 161-84, at p. 166.

19 Compare John Bell, Londons remembrancer (London, 1665), sig. [A4], who defends the searchers in terms of the 'eminentest men of the Parish' who selected them.
} 
and the bribe of a Two-groat fee' was possibly intended less as a slur on women, than as a calculated comment on the Cromwellian legislation of 1653 which provided for a civil parish registrar who could take fees. ${ }^{20}$ Compared with abusive comments of similar date about midwives and plague nurses, Graunt's tone can only be described as moderate.

Turning from the incidental to the systematic, what did Graunt have to say about all women? The systematic aspects of his writing must include his terminology. It is worth noting that early modern English included a rich vocabulary of ostensibly gender-neutral collective nouns - for example child, children, infants, idiots, impotents, inhabitants, persons, parties, heads, people, saints, sinners, and souls. This subject has been considered by Hilda Smith, who would regard many of these terms as what she calls 'false universals'. That is, an apparent inclusiveness can be found to conceal an often deliberate exclusion of women. However, Smith's interpretation is not always applicable. Most early modern literature does take the male example as universal, but this was not necessarily unthinking. Some early modern writers use or comment upon masculine language, for example in the Bible, but state explicitly that this is intended to include women. Admittedly, less care was taken outside the contested areas of theological debate, and inbuilt assumptions were allowed to dominate; for example, 'woman' could be conflated with 'wife'. ${ }^{21}$ But Graunt is arguably another exception to Smith's generalization. As we shall see, Graunt regarded the failure to distinguish by sex as a problem, and was unusual in trying to overcome it. In referring to women of child-bearing age, he used the expression 'teeming women' which might be found offensive because it was also used for lower animals. ${ }^{22}$ This, I would suggest, is a retrospective judgement. More contentious is his use, for both humans and lower animals capable of fertility, of 'breeders', another term which was also used by Petty. 'Breeders' can be said to have attracted a weight of negative connotation as a result of its devastating deployment by Jonathan Swift in his Modest proposal, which drew satirically on Graunt's work but more particularly on Petty's. The term was later used in a pejorative context by David Hume. However, it does not seem plausible to trace the negative life of this term back to Graunt, who applies it to men as well as women, without the class or ethnic implications it later acquired. ${ }^{23}$

20 This is Hull's suggestion: Graunt, Observations, ed. Hull, II, p. 35 . Very little seems to have been written about this legislation, but see D. Woodward, 'The impact of the Commonwealth Act on Yorkshire parish registers', Local Population Studies, 14 (1975), pp. $15^{-31}$. For a different interpretation, see R. Munkhoff, 'Reckoning death: women searchers and the Bills of Mortality in early modern London', in Jennifer C. Vaught, ed., Rhetorics of bodily disease and health in medieval and early modern England (Farnham, 2010), pp. 119-34, at p. 131.

${ }^{21}$ Hilda L. Smith, All men and both sexes: gender, politics and the false universal in England, I $640-$ ${ }_{1} 832$ (University Park, PA, 2002); Margaret R. Sommerville, Sex and subjection: attitudes to women in early modern society (London, 1995), pp. 44-5, 56, 68.

${ }^{22}$ Graunt, Observations, ed. Hull, II, p. 367 . For Petty, see ibid., II, pp. 6o4-5.

${ }^{23}$ G. Wittkowsky, 'Swift's Modest proposal: the biography of an early Georgian pamphlet', Journal of the History of Ideas, 4 (1943), pp. 75-104, esp. pp. 96ff; P. M. Briggs, 'John Graunt, 
The most important systematic aspect of Graunt on women was that he counted them - literally and perhaps also figuratively. As he pointed out, he was hampered by the fact that no distinction of sex was recorded in the Bills until 1629 , when information on different causes of death, which had been collected earlier, was also published for the first time. In 166o, two years before the Observations first appeared, distinction by sex was extended to Westminster and the out-parishes. ${ }^{24}$ Graunt himself tried to discover the reasons for these changes, but was frustrated:

Nor could I ever yet learn (from the many I have asked, and those not of the least Sagacity) to what purpose the distinction between Males and Females is inserted, or at all taken notice of? or why that of Marriages was not equally given in? Nor is it obvious to every body, why the Accompt of Casualties...is made? The reason, which seems most obvious for this lat $[\mathrm{t}] \mathrm{er}$, is, That the state of health in the City may at all times appear. ${ }^{25}$

Unfortunately, it appears that no more is known now about these changes than was known to Graunt, although it is intriguing that no one he spoke to was able to explain them. ${ }^{26}$ Graunt's tone here is not that of a campaigner for the rights or merits of women, nor did his work on the sex ratio lead to any consistency in the counting of females as well as males. Later insurance schemes, for example, failed partly because they neglected to take account of age or sex, and some eighteenth-century political arithmeticians elsewhere in Europe also did not distinguish by sex. ${ }^{27}$

This is not to suggest that women were entirely invisible in systematic recordkeeping by the church, the state, or local government. They were most visible in the commonest types of early modern census-taking, those relating to burdens on the state or sources of instability. Graunt brought forward many concerns of this type in his conclusions. Hence, we find that before Graunt's time women were itemized, if not separately totalled, among the poor, or aliens, or religious refugees. In the Norwich census of the poor for 1570 , which is remarkably comprehensive among extant censuses in early modern England, as much detail is

Sir William Petty, and Swift's Modest proposal, Eighteenth-Century Life, 29 (2005), pp. 3-24, esp. pp. 9, 16; David Hume, Political discourses (Edinburgh, 1752), p. 174; Graunt, Observations, ed. Hull, II, pp. $372 \mathrm{ff}$.

24 Graunt, Observations, ed. Hull, I, pp. Ixxxvii-viii, II, p. 342. Graunt appends tables for several 'country-parishes' where distinction by sex for burials was recorded as early as 1560 : ibid., II, pp. 412-21, 430-1.

${ }^{25}$ Ibid., II, p. 347, in ch. II, 'General observations upon the casualties'. Bell, Londons remembrancer, traces the evolution of the Bills but does not mention distinction by sex.

${ }^{26}$ Robertson suggests that the reason was contemporary awareness of greater female mortality from plague: J. C. Robertson, 'Reckoning with London: interpreting the Bills of Mortality before John Graunt', Urban History, 23 (1996), pp. $325^{-5}$ o, at pp. $33^{2-3}$.

27 Bonar, Theories of population, p. 196; Amy Froide, Never married: singlewomen in early modern England (Oxford, 2005), p. 2; Joshua Milne, Treatises on the law of mortality (1837), facs. repr. in E. Halley et al., Mortality in pre-industrial times: the contemporary verdict (Westmead, 1973),

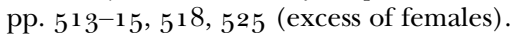


given about women and children as about men, and social policies were constructed accordingly. Specific numbers of women (often lumped in with children) could also be cited when their presence proved something important, like victory in war, or the seriousness of a riot. ${ }^{28}$ We will observe further examples of this later.

The counting or otherwise of women ideally needs to be put in the context of how likely it was that comprehensive, as opposed to purpose-specific, counting would be carried out at all. During the early modern period most (but not all) Englishmen were in favour of populousness, that is, they saw increased population as an important indicator of national success. A shrinking population was a warning of decline, especially in comparison with other countries. This concern increased over the course of the seventeenth century, in the context of international rivalries and loss of population caused by plague, emigration to the New World, and civil war. ${ }^{29}$ However, in spite of the strength with which this view was held, England continued reluctant, even in later periods, to number its people, of both sexes. $3^{\circ}$ Graunt urged the usefulness of such information, including distinction by sex, for trade and successful colonial plantationpointing towards, among many other things, the role of women as consumers:

It is no less necessary to know how many People there be of each Sex, State, Age, Religion, Trade, Rank, or Degree, \&c. by the knowledge whereof, Trade and Government may be made more certain and Regular; for, if men knew the People, as aforesaid, they might know the consumption they would make.

However, Graunt is also careful to suggest that such information might be appropriate only for the ruling elite. $3^{11}$

To political caution can be added religious restrictions on any comprehensive census-taking, which were far from token at this time. The source of this reserve was the biblical story in which King David was severely punished by God for numbering his people. David's choice of punishment meant that thousands of these same people died of pestilence. David's high profile in the seventeenth century was partly due to the tendency of post-Reformation Protestantism to replace New Testament figures with those from the Old, and for Graunt, as for so many others, he was a natural point of reference. David was of course

${ }^{28}$ Graunt, Observations, ed. Hull, II, pp. 396-7; J. F. Pound, ed., The Norwich census of the poor I570 (Norfolk Record Society, [Norwich], 1971); Francis Bacon (and Francis Godwyn), The history of the reigns of Henry the Seventh... and Queen Mary (London, 1676), pp. 22 (1517, May Day riots), 110 (1544, siege of Boulogne).

29 See for example Bonar, Theories of population; Mildred Campbell, “'Of people either too few or too many": the conflict of opinion on population and its relation to emigration', in W.A. Aiken and B. D. Henning, eds., Conflict in Stuart England (London, 196o), pp. 169201; P. Slack, 'Plenty of people': perceptions of population in early modern England (Stenton Lecture, Reading, 2011).

$3^{\circ}$ Kreager, 'Histories of demography', pp. 522-3.

$3^{1}$ Graunt, Observations, ed. Hull, II, pp. 396-7, 347. Compare Kreager, 'Graunt, John', pp. $162-3,166$. 
an ideal of kingship and leadership, the 'man after God's own heart', as well as an object lesson. ${ }^{2}$ For both the Anglican clergyman Thomas Adams, and the 'Free-Willer' Henry Adis, David's sin was one of pride, and a dire warning of how the anger of the Lord against one man could lead to the suffering of a whole nation. 33 Such commentary had obvious resonance after the execution of Charles I and in a half-century punctuated by plague. A contrary line was taken by John Bell, clerk of the Company of Parish Clerks, who asserted that because both men and women died in the London plagues, this distinguished them from God's punishments of kings, like David, as a result of which only men died. 34

Graunt himself declared that he was worried by the example of David, but decided to set it aside, having 'examined the lawfulness of making such Enquiries', and under the 'provocation' of hearing men of reputation and experience making baseless claims as to the great size of London's population. With his usual briskness, Graunt does not expand on whom or what he examined to find out whether numbering the people was lawful. His own solution to the Davidic problem was to work from the Bills, together with Richard Newcourt's map of London of ${ }^{1} 6_{5} 8$, and his own estimates of 'teeming women' and family size. As far as both Graunt and Petty were concerned, no equivalent of a census of London had been taken since $163_{1}$; the next best thing was the poll tax listings of 1640.35

\section{I I}

David's sin of pride was not the only problem he posed for his admirers. Along with other important Old Testament figures, such as Solomon, David took a great many wives as well as concubines. The first practiser of polygamy was said to be Lamech, who was also a murderer. $3^{6}$ This aberrant behaviour on the part of the patriarchs was explained by some on the basis that God had licensed a departure from the ordained relationship between men and women because Israel was beleaguered by pagans multiplying polygamously,

$3^{2}$ II Samuel c. 24; Tessa Watt, Cheap print and popular piety, 1550-I640 (Cambridge, 1996), pp. $115^{-16}$, 126, 201-2; Graunt, Observations, ed. Hull, II, pp. 350, 352; C. Hill, The English Bible and the seventeenth-century revolution (Harmondsworth, 1993), pp. 77, 96, 262, 347, 377, 379, 404 .

33 Thomas Adams, God's anger, and man's comfort: two sermons (London, 1652/3), pp. 18, 52 , 53; Henry Adis, A fannaticks mite cast into the kings treasury (2nd edn, London, 166o), pp. 38-9.

34 Bell, Londons remembrancer, sig. [D2v]. On sex ratios in plague mortality, see P. Slack, The impact of plague in Tudor and Stuart England (London, 1985), pp. 179-81.

35 Graunt, Observations, ed. Hull, I, p. lxvii, II, pp. $3^{8} 3^{-6}$, 401 , 405; Bonar, Theories of population, p. 79. Modern demographic historians have made good use of the 'Settlement of tithes 1638 ', but this listing was limited to householders only: Finlay, Population and metropolis, pp. $71 \mathrm{ff}$.

${ }_{36}^{6}$ Henricus Cornelius Agrippa, The glory of women: or, a treatise declaring the excellency and preheminence of women above men, trans. E. Fleetwood (London, 1652), p. ${ }_{15}$. 
and needed to increase its strength. 37 In a climate of opinion that favoured populousness and perceived threats from outside, the danger of extrapolating from this argument was obvious. In the second of his dedicatory epistles, to John Robartes, lord privy seal and a member of the privy council, Graunt submitted a list of reassuring truths, as opposed to mistaken ideas, that it 'doth not ill become' someone in Robartes's position to consider. These included: 'That the opinions of Plagues accompanying the Entrance of Kings, is false, and seditious', that 'the wasting of Males by Wars and Colonies do not prejudice the due proportion between them and Females', and that 'the irreligious Proposals of some, to multiply people by Polygamy, is withal irrational, and fruitless'.

In his text, Graunt discusses polygamy in the chapter on 'the difference between the numbers of Males and Females', making a direct link between his new-found sex ratio and the case against polygamy:

That Christian Religion, prohibiting Polygamy, is more agreeable to the Law of Nature, that is, the Law of God, than Mahumetism, and others, that allow it; for one Man his having many Women, or Wives, by Law, signifies nothing, unless there were many Women to one Man in Nature also. $3^{8}$

He goes on to assert that a nation practising polygamy and wishing to increase its population would also have to castrate some of its males - an argument likely to make men attracted to the idea of polygamy think twice - and that celibacy, as practised in Catholic countries, would hinder population growth unless as many women chose the single life as did men. Here, Graunt is effectively both claiming that a near-equal sex ratio was universal among human beings, and enshrining it as an aspect of natural law.

In his conclusion to this chapter, he comes closest, not to arguing for greater rights for women, but to suggesting that English society at least offered some form of equality between men and women, and that this should be preserved: 'It is a blessing to Mankind, that by this over-plus of Males there is this natural Bar to Polygamy: for in such a state Women could not live in that parity and equality of expense with their Husbands, as now, and here they do.' A polygamous husband, to keep his wives 'all quiet' with each other and with himself, would have to keep them all 'in greater aw, and less splendour', leading to an abuse of the power he undoubtedly had, to keep them all as low as he pleased, 'the poorest Subjects, (such as this plurality of Wives must be) being most easily governed'.39 This might be read as an invitation to the powerful to oppress the weak, women included, but Graunt's strategy appears to be one of flattering his countrymen (who so often complained of the

37 Biller, Measure of multitude, p. 41; Sommerville, Sex and subjection, p. 164; [Bernardino Ochino], A dialogue of polygamy (London, 1657), pp. 13-14, 21-3, 53 .

$3^{8}$ Graunt, Observations, ed. Hull, II, pp. 320,374 .

39 Ibid., II, pp. 377,378 . 
expensive habits of their wives, and who had just come through a civil war) by implied comparisons with nations who kept their women in subjection in polygamous households, and who so impoverished their subjects that the latter had no will to resist, thereby at the same time inhibiting consumption and trade.

Polygamy, or more accurately polygyny, has been a common form of human marriage (as opposed to polyandry, which is very rare). Graunt's contemporaries were well aware of this feature of comparator societies, of which the most obvious and threatening example was the Turkish empire expanding in the Middle East. Given the predominance of theological discussion, it is not surprising that the bulk of commentary at this period on polygamy relates to the Old Testament examples, one of the problems for theologians being that the New Testament said nothing unambiguous about it. As Sommerville shows, few argued in favour of polygamy, but most theorists felt obliged to condemn it. Historians looking for debates about polygamy have usually found greater interest in the long eighteenth century and the Enlightenment. Aldridge's excellent articles place their emphasis on the 'hundred years of debate' which followed the 1675 Bill to repeal the Jacobean law against polygamy, and more recently Blum has discussed the issue for eighteenth-century France. $4^{\circ}$

Why then did polygamy become an issue for Graunt, and, by implication, for wider society in the earlier period? We may infer that, if Graunt's contemporaries believed there was an excess of women, this meant for them large numbers of women on the loose - at their own hands, and in control of their own property. As a result of the Reformation, neither women nor their property could any longer be safely absorbed by the institutions of the church. The desacramentalization of marriage by religious reformers was accompanied by rare but striking instances in which polygamy was tolerated if not actually recommended. Any form of subordination, this suggested, was better than none, although a central concern was also the satisfaction of male desires, including for procreation, in the absence of divorce. $4^{1}$

Clearly, some of these issues were in Graunt's mind, or thought by him to be in the minds of his contemporaries. However, there are other reasons, specific

$4^{\circ}$ D. Herlihy, 'Biology and history: the triumph of monogamy', Journal of Interdisciplinary History, 25 (1995), pp. 571-83; Sommerville, Sex and subjection, pp. 151, 16o; A. O. Aldridge, 'Polygamy and deism', Journal of English and Germanic Philology, 48 (1949), pp. 343-6o; A. O. Aldridge, 'Population and polygamy in eighteenth-century thought', Journal of the History of Medicine, 4 (1949), pp. 129-48; A. O. Aldridge, 'Polygamy in early fiction: Henry Neville and Denis Veiras', Publications of the Modern Language Association, 65 (1950), pp. 464-72; Carol Blum, Strength in numbers: population, reproduction, and power in eighteenth-century France (Baltimore, MD, 2002), ch. 5. But see Anne McLaren, 'Monogamy, polygamy and the true state: James I's rhetoric of empire', History of Political Thought, 25 (2004), pp. 446-8o, esp. pp. 469-75; L. Miller, John Milton among the polygamophiles (New York, NY, 1974); J. Cairncross, After polygamy was made a sin: the social history of Christian polygamy (London, 1974).

$4^{1}$ Sommerville, Sex and subjection, p. $15^{1}$; D. Jonathan Grieser, 'A tale of two convents: nuns and Anabaptists in Münster, 1533-1535', Sixteenth Century Journal, 26 (1995), pp. 31-47; Miller, John Milton, pp. 13-23; Cairncross, After polygamy was made a sin. 
to the 165 os and 1660 s, why he would have seen polygamy as an important rather than peripheral concern. The most striking of these is the publication in 1657 of a notorious dialogue on polygamy by Bernardino Ochino, the sixteenth-century Italian reformer and associate of Peter Martyr (Vermigli). Together with Vermigli, Ochino, by then a religious exile, was invited to England in 1547 by Thomas Cranmer to assist with the reform of the English church. Although he never learned English, Ochino was a charismatic preacher and fourteen of his sermons were translated and published by Anne Cooke, later Lady Bacon, one of a notable highly placed group of women writers who were 'sustainers' of the Protestant cause under Edward and Mary. Ochino's provocative dialogue on polygamy was published after he had left England, in ${ }^{1} 5^{6} 3$, together with other controversial opinions including antiTrinitarianism. It was during this period that he came under the direct influence of Lelio Sozini, the joint originator of Socinianism. The hostile reaction to Ochino's dialogue on polygamy caused his final dismissal by Heinrich Bullinger and the Zurich city fathers. $4^{2}$ The dialogue did not appear in English until it was translated by Thomas Pecke, the friend of Francis Osborne, following the succès fou of Osborne's Advice to a son $(1654 / 5$ and 1658). Osborne's Advice was a cynical and arguably misogynistic skit on prescriptive literature which praised polygamy and dismissed single marriage as a mere invention of the church. Osborne (1593-1659) was 'puritanically educated', a reputed atheist and friend of Thomas Hobbes, and also published on the Turks $(1656)$ and on paradoxes (1659).43 Pecke's translation of Ochino was anonymous, as by 'a Person of Quality', but was prefaced with an epistle to Osborne. The royalist astrologer and alchemist John Heydon seized the opportunity to reply, scurrilously, to both Osborne and Pecke, abusing Pecke as both the author of the translation and the mouthpiece of Osborne. In a second work purporting to support the cause of women, published in the following year (1660), Heydon similarly promotes himself and his practice of physic, while entertaining his readers with salacious gossip and bawdiness. Though arguing that not all women were whores, he defends whoredom as the least of the evils on offer, adding: 'Well then, sirrah, is not using a handsom Girl wholsome, pleasurable, and tollerable: For since the number of females do far exceed that of males, doubtless they would have a little of that same aswell as the rest of

$4^{2}$ M. Taplin, 'Ochino, Bernardino (c. $14^{8} 7^{-1} 5^{64 / 5}$ )', ODNB; Anne Overell, Italian reform

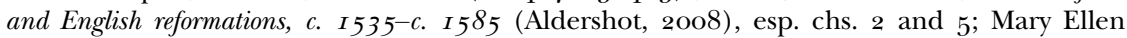
Lamb, 'The Cooke sisters: attitudes toward learned women in the Renaissance', in Margaret P. Hannay, ed., Silent but for the word: Tudor women as patrons, translators and writers of religious works (Kent, $\mathrm{OH}, 1985$ ), pp. 107-25. On the Dialogue, its status as a plagiarism, and Ochino's defence of it in old age, see also P. McNair, 'Ochino's apology: three gods or three wives?', History, 6o (1975), pp. 353-73.

43 [Ochino], Dialogue of polygamy; Francis Osborne, Advice to a son (6th edn, Oxford, 1658). For Osborne, see Marie C. Henson, 'Osborne, Francis (1593-1659)', ODNB; S. A. E. Betz, 'Francis Osborn's Advice to a son', in R. Shafer, ed., Seventeenth-century studies (2nd ser., Princeton, NJ, 1937), pp. $3^{-67}$, esp. pp. $5^{\mathrm{O}-67}$. 
their fellow Creatures, who are all flesh and blood.' Heydon mentions the excess of women in passing as a matter of known fact, providing corroboration of Graunt's equally matter-of-fact assumption that this was what all men thought. In spite of his outcry against Pecke and Osborne, Heydon allows further latitude to his readers in stating polygamy to be a 'lawful provision made in this Case of Extremity', that is, when a man lacking the gift of continence could not lie 'with his own wife, nor his neighbors wife, nor his mayd, his nurse, nor with a whore'. This 'best Expedient for generation and Continency, and strictest way to have few or no whores at all' was that followed by the Turks. 44

Some may see Ochino now as an obscure figure, overshadowed by Vermigli in the sixteenth century and given only fleeting notoriety in the seventeenth by Pecke's translation and its association with the worldly iconoclasm of Osborne. In fact, Ochino appears to have had a surprisingly persistent afterlife in English writing, being revered on the one hand as one of the authors of the English Reformation, and reviled on the other for his espousal of polygamy and anti-Trinitarianism. 45 Some, like Sir Thomas Browne, a major writer who also assumed an excess of women, could countenance polygamy - 'which considering some times, and the unequal number of both sexes, may be also necessary' while repudiating Ochino as a 'Machiavel' and 'that Villain and Secretary [sic] of Hell, that composed that miscreant piece of the Three Impostors'.$^{6}$ Browne wrote in a very different style and genre from Heydon but, like him, linked polygamy with an unequal balance between the sexes. Browne had some reason to see Ochino as a cynic, a Machiavel, as well as a man of extreme religious beliefs. Ochino's dialogue on polygamy does not read like a serious work of religious conviction. Rather, it is an urbane, almost casual balancing of often affronting views which prevents the reader from determining Ochino's own level of responsibility. This tendency in Ochino's writing exasperated his critics and was duly exploited by Pecke in presenting the dialogue on polygamy to the public. The stationer responsible for the publication, John Garfeild, took the

44 Eugenius Theodidactus [John Heydon], Advice to a daughter, in opposition to the Advice to a son (2nd edn, London, 1659); [John Heydon], The ladies champion (n.p., 166o), pp. 5-6, 8 (ref. to Ochino). See I. W. McLellan, 'Pecke, Thomas (b. 1637, d. in or after 1664)', ODNB; P. Curry, 'Heydon, John (b. 1629, d. in or after 1670)', ODNB. On the authorship of the ${ }_{16} 6_{57}$ Dialogue and its impact, cf. Miller, John Milton, pp. 28-33.

45 See for example William Lucy, Observations, censures and confutations of notorious errours in Mr. Hobbes his Leviathan...to which are annexed, occasionall animadversions on some writings of the Socinians (London, 1663), pp. 315 $5^{-17}$; [S.J. Brown] [?Evan Griffith, John Clement Gordon], Pax vobis: or, gospel and liberty: against ancient and modern papists ( $5^{\text {th }}$ edn, n.p., 1687), Preface and pp. 7-8, 43, 61, 63. Further editions of the Dialogue appeared in the 173 os: Aldridge, 'Polygamy and deism', pp. 345-7.

$4^{6}$ Thomas Browne, Religio medici (1643; edn of 1682), in C. Sayle, ed., Works (3 vols., London, 1904; Edinburgh, 1907), I, pp. xxviii, 32-3 (pt I, sect. 20), 100 (pt II, sect. 9). 
further precaution of setting out the distinction between polygamy and bigamy, the latter being punishable by death. 47

In the dialogue, Ochino's characters, Telypolygamus and Ochinus, spend much time debating Old Testament figures, with Telypolygamus arguing that it was a mistake to think that the Old Testament was not sufficient to teach all things necessary to salvation. $4^{8}$ Ochino deals with various matters which are also points of reference for Graunt - the sins of David (including numbering the people); the behaviour of lower animals (especially birds) and its modification by castration; populousness; and the relationship of plurality of wives to natural law. Ochino's characters also deal explicitly with the sex ratio:

Tel. If there were in the world as many Men as Women, I confess it were expedient, that every man should have his own single Wife. But seeing the number of Women is greater, I conceive it fit, that one man have many Wives; for it is not in vain, that God makes more Women... The life of one Man equalls that of two Women.

Telypolygamus is here claiming the exact opposite of Graunt's conclusion that God provided, if anything, a slight excess of males. The opposing character, Ochinus, who is often given rather feeble lines, here makes a response which a modern reader is likely to find very much to the point: ' $O c h$. In the first place, I do not believe that you know there are more Women in the World then men. Perhaps it seemes so to you, because commonly we rejoyce at the birth of Boyes, and grieve at the birth of Girles.' However, Telypolygamus does not give way, returning to make an objection which, as we have seen, was raised subsequently in a much more barefaced way by Heydon:

Tel. Suppose there are more Women then Men, what shall the poor Women do in this case?

Och. They must do, just as the men should do, in [the] case there were many more Men then Women, viz. pray to God to give them the gift of continence. 49

As Heydon was to do, Telypolygamus also asserts in reply that it is useless for men to pray for the gift of continence, because God had called on them to marry.

It is hardly surprising that Graunt makes no reference to Ochino in the Observations, in that he follows common practice in providing no such references at all, apart from naming his dedicatees. Nonetheless, he could well have had weighty reasons for suppressing all reference to Ochino, whose religious views might have been too much a reminder of his own, whether he had moved on from Socinianism or not. By the same token, Ochino's complex of controversial views may have provided Graunt with a powerful

47 See B. Capp, 'Bigamous marriage in early modern England', Historical Journal, 52 (2009), pp. $537-56$.

$4^{8}$ [Ochino], Dialogue of polygamy, Stationer to the Reader, p. 25.

49 Ibid., pp. 61, 62, 83. My italics. 
motive for putting opposite cases. It seems at least likely that Ochino, Osborne, and Pecke were among those whom Graunt meant in referring to 'the irreligious proposals of some, to multiply people by Polygamy'. $5^{\circ}$

By establishing in numerical terms that there were no 'excess' women, Graunt was ensuring that the argument for polygamy could be undermined. The equality of the sex ratio was later used as ammunition against polygamy by Patrick Delany among others. By further arguing that polygamy did not increase population, Graunt was reassuring his readers that the Turkish 'other' was neither favoured by God nor an example to follow. It also became harder, after Graunt, for his contemporaries to argue that a parallel existed between England and ancient Israel which entitled Englishmen to reproduce outside single marriage. This was pleasing to those who, like Sir Kenelm Digby, saw in the views of radical Protestants like Ochino an inevitable and dangerous progression from heretic to Jew to Turk. As it appeared in England in the $16_{5}$ os, the argument in favour of polygamy was perhaps less to do with religious radicalism than with libertinism and the lapse of censorship, but the two were brought together in the context of contemporary fears of sectaries and the attempt to discredit their way of life. The major phase of the debate over marriage, divorce, and polygamy, including Milton's involvement and Thomas Edwards's Gangraena, does of course belong to the 1640 , leading up to the Adultery Act of $16_{5}$. This makes it more likely that Graunt, publishing in 1662, was prompted in part by Pecke's translation of Ochino of 1657 . However, the earlier phase of the debate did clearly set out the intimate relationship between human marriage and the aims of government and politics, of which Graunt showed himself to be aware. $5^{1}$

\section{V}

The above suggestions might help explain Graunt's motivations, but they only begin to account for why Graunt's contemporaries thought there were too many women. As already indicated, early modern men were most likely to 'number' women when there were too many women of a problematic kind or when they themselves felt outnumbered. These occasions could include too many poor widows needing pensions, too many stray maidservants ending up in Bridewell, or too many women gossiping together at the conduit or in the alehouse. It seems safe to assume that there was a sense in which one woman out of place, or insubordinate towards her male connections, was one woman too

$5^{\circ}$ Graunt, Observations, ed. Hull, II, Ep. Ded. to Robartes, p. 320 . For Petty's critical appraisal of Advice to a son and its reputation, see Pepys, Diary (27 Jan. 1664).

$5^{1}$ Aldridge, 'Polygamy and deism', pp. 351, 355; Kenelm Digby, Observations upon Religio medici (London, 1643), p. 33; Cairncross, After polygamy was made a sin, pp. 126-36; K. Thomas, 'The puritans and adultery: the act of $16_{5}$ o reconsidered', in D. Pennington and K. Thomas, eds., Puritans and revolutionaries (Oxford, 1978), pp. 257-82; Mary Fissell, Vernacular bodies: the politics of reproduction in early modern England (Oxford, 2004). 
many, and that any clustering of women, especially outside the household, was a cause of unease if not actual repression. Women were supposed to marry, and a marriage absorbed the woman, creating one flesh from two. Bernard Capp has shown that only women acting in concert, rather than singly, were likely to gain their point over men. It might follow from this that any man emerging from such an experience would carry away an abiding impression of 'far too many women'. As already suggested, independent women were the most worrying, and given an excess of women, there would inevitably be more of these.

It is true that, as in the arguments of Telypolygamus and Heydon, an excess of willing or available women, as in a brothel, could imply abundant sexual gratification for the male, and, short of that, could be flattering to men. In Tis merry when gossips meet (1613), a young man and his lute keep company with a maid, a wife, and a widow - the three recognized stages of life of a woman perhaps having something to do with the 'three women to one man' notion referred to by Graunt. However, as with Paris's encounter with the three graces, or with women lamenting a lack of men, there might always have been an undercurrent of danger, whether welcome or not. 'Complaining virgins' might assert that 'when before one woman, (by report) would have served twenty men, one man must be faine to serve twenty women' - this was on the one hand a delightful prospect, but on the other frightening, as 'all they can do [is] not sufficent [sic] to content us maids'. $5^{2}$

In general in early modern society, in spite of the stress on qualities and the reluctance to count with any precision, any sense of threat (from, for example, opposing armies, or rival nations, or even the rapid expansion of London) readily translated itself into excess numbers. In this region of cultural perceptions, it is important to note that the quantitative and the qualitative could overlap. In what way might women have been seen as especially threatening in the mid-seventeenth century? The Swetnam controversy and similar outbursts of misogynistic feeling belong earlier, and it has been posited that, if there were a crisis in gender relations at this period, it had passed its peak by 1640. However, the existence of a peak does not mean that the level reverts to zero. It seems more plausible, given the unnerving events of the 1640 os and 165 os, that anxieties about women merely changed focus and means of expression. As already suggested, the literature dating from around 1640 , and probably written by men, in which women lamented their lack of male partners, necessarily implied a glaring overplus of women. The Virgins complaint of 1643 , for example, is signed by 'five thousand, or thereabouts' of pure virgins under fourteen, and 'mature Maids, and supposed Virgins, to the number of

$5^{2}$ B. Capp, 'Separate domains? Women and authority in early modern England', in P. Griffiths, A. Fox, and S. Hindle, eds., The experience of authority in early modern England (Houndmills, 1996), pp. 117-45, esp. pp. 127, 136; [Samuel Rowlands], Tis merrie when gossips meete: newly enlarged, with divers merry songes (London, 1613); Anon., The virgins complaint for the losse of their sweet-hearts (London, [1643]), p. 5. 
two hundred thousand in the whole Kingdome'. Amy Froide sees the increasingly vicious stereotype of the old maid - a stereotype apparently emerging first in England - as originating in the 1640s.53 Crawford and others have made clear that publishing by women - that is, their presence under the eyes of men most likely to leave written records themselves - reached unprecedented levels at this period. The crowds of women petitioning and besieging parliament must have been even more disturbing, because more visible. The numbers of women given as involved in this extraordinary political activity are suspiciously rounded, suggesting an overlap between the qualitative and the quantitative, but this resort to number was still unusual, even in accounts of women rioters and imaginative reconstructions of female-dominated societies such as the Amazons. Also well documented for this period is the high proportion of women in sectarian congregations. While only Quakers adopted a system which facilitated the formal collective presence of women, preachers must often have gazed out at a sea of female faces, which, like the women petitioners, were literally visible. Phenomena such as these involved women acting in mutual solidarity (if not conspiratorially) and across class divides, and a reaction against them was part of the backlash of the 1660 . 54

These highly visible women were nonetheless still subordinate to male-dominated institutions - parliament, the church (or churches), even the printing trade. Woman's distinctive ability to reproduce, on the other hand, seemed still to be outside men's control. The example of Mary having shown what was possible, a few women prophets in the $16_{5}$ os had the temerity to lay claim to virgin births - the ability to do without men altogether. The theological dimensions of this claim were worrying enough, but it also chimed with a fear which men themselves knew men actually felt - that many women would have been happy to do without men entirely:

For in the old Law, it was a curse upon Women to be Barren: and surely if there had beene any lawfull way for them to have had Children without Husbands, there hath beene, and are, and will bee a numberlesse number of Women that would or will never be troubled with wedlocke, nor the knowledge of man.

53 Anon., The virgins complaint, p. 7; no rationale is given for these figures. Froide, Never married, p. 220.

54 Froide, Never married, cf. pp. 22, 160-1; Patricia Crawford, 'Women's published writings, 1600-1700', in Mary Prior, ed., Women in English society, I 50o-I80o (London, 1985), pp. $211-$ 82; Patricia Higgins, 'The reactions of women, with special reference to women petitioners', in B. Manning, ed., Politics, religion and the English Civil War (London, 1973), pp. 179-222; Anne Laurence, 'A priesthood of she-believers: women and congregations in mid-seventeenthcentury England', in W. Sheils and D. Wood, eds., Women in the church (Studies in Church History, 27, Oxford, 1990), pp. 345-63; Patricia Crawford, 'The challenges to patriarchalism: how did the Revolution affect women?', in J. Morrill, ed., Revolution and Restoration: England in the I 650 os (London, 1992), pp. 112-28; Phyllis Mack, Visionary women: ecstatic prophecy in seventeenth-century England (Berkeley, CA, 1992); Fissell, Vernacular bodies. 
'Numberlesse number' neatly sums up the overlap between the quantitative and the qualitative suggested above. This author, usually identified as male, also raised, as did Ochino, the spectre of polyandry, as a response to the liberty assumed by men in taking many wives. 55

The women claiming to have given birth without men were not the only female prophets causing concern after 1640. Before this date, prophecies tended to be transmitted orally; Keith Thomas has pointed to an escalation associated with the circulation of prophecies in print from 1641 . The prophecies he identifies as the 'best known of all' were those of Mother Shipton, who, like Ochino, was reincarnated from the sixteenth century. Her predictions were published in various forms at least twenty times between $164_{1}$ and 1700 . They seem grounded in historical anecdote, but there is no evidence that Mother Shipton actually existed, or that she was a known figure before 1641 . As the images included in successive editions of her prophecies show, she rapidly transformed from Tudor woman or generic sybil into stereotypical aged crone or witch (or Mrs Punch). Various legends became attached to Mother Shipton, but her relevance here lies in her original message, which was political and anti-clerical. In 1645, William Lilly included her prophecies among 'the remaining monuments of good men' that wished well to their country, adding that her words were 'never yet questioned either for the verity or antiquity; the North of England hath many more of hers'..$^{6}$

The basic Mother Shipton story involves her predicting that Cardinal Wolsey would never complete his journey to York. Wolsey ordered several lords to visit her, and in the course of this encounter she outwitted them by her foreknowledge, affirmed her original prophecy, and made several more, mainly forebodings of political revolutions and military disasters, often cryptically expressed. Towards the end of these she said: "And after this shall be a white Harvest of corne gotten in by women. Then shall be in the North, that one woman shall say unto another, Mother I have seene a man to day, and for one man there shall be a thousand women.' 57

This acute shortage of men, such that women had to bring in the harvest, and the sighting of a single man became a remarkable event, was ostensibly related to a particular place and set of conflicts, but was readily seen as pertinent to a period suffering the depredations of civil war. It seems reasonable to suppose that Mother Shipton's prophecies found an audience outside London, but

\footnotetext{
55 Mack, Visionary women, p. 117 ; Anon., The womens sharpe revenge (London, 1640), pp. 134, 117 ; [Ochino], Dialogue of polygamy, pp. 47-9, 83 .

$5^{6} \mathrm{~K}$. Thomas, Religion and the decline of magic (Harmondsworth, 1980), pp. 465, 486, 49off; [Ursula Shipton], Mother Shipton: a collection of the earliest editions of her prophecies (Manchester, [1882]); T. Thornton, Prophecy, politics and the people in early modern England (Woodbridge, 2006), esp. pp. 6o-98; William Lilly, A collection of ancient and moderne prophesies concerning these present times (London, 1645), Preface to the Reader and pp. 35-9; see also pp. 13, 20-1.

57 Anon., The prophesie of Mother Shipton (London, 1641). The image used for this early edition is of a woman in Tudor dress, of no particular age.
} 
their effect is most easily detected in the metropolis. $5^{8}$ We have seen that the loss of fighting men and its effects was one of the points on which Graunt was concerned to offer reassurance.59 The midwives just petition of 1643 and ${ }_{1} 646$ deplored 'a naturall depopulation of towns and Cities' as a result of the absence of husbands and consequent reduction in the birth rate, as well as 'Kenton Battayle' in which worthy men were lost 'to the number of $75^{63}$ ' this unusually precise total being apparently based on the evidence of parish officers. Without men, 'their instruments of conjunction and delight', women were 'but halfe themselves, and being indeed nothing in themselves, from them they receive perfection, weight and number' - a sly reference to the effects of pregnancy and birth, but also a significant one in this context. This author, again probably a man, goes on to refer directly to Mother Shipton's warnings about damage to the sex ratio:

Moreover we have just cause to feare those dreadfull prophesies which point so directly at this age, foretelling that there should be a great scarcity of men, and such abundance of women farre exceeding the other, both in strength and number, so that a hundred should run after one, being a fearefull prodigy in nature, and a dearth to be more feared, then that of Corne or any other commodity. ${ }^{60}$

References to Mother Shipton at this period are many and various. A mocking doggerel of around the Restoration period has 'Queen Dowager Cromwel' brooding over 'Shipton Wife's Prophecy', and the poems of Henry Bold, crude and otherwise, refer to both the political and the sexual implications of her prophecies. ${ }^{61}$ Graunt's dedication to Moray may seem entirely directed at the natural-philosophical aims and objects of the Royal Society, but it is also the case that Moray was interested in political prophecies and could hardly have been unaware of the Mother Shipton craze, which underlined the perils of too few men as well as too many women. ${ }^{62}$

\section{$\mathrm{V}$}

In conclusion, it seems that Graunt was right in stating that his contemporaries thought there were more women than men. There was seemingly no necessity

$5^{8}$ Thornton's very thorough discussion in Prophecy, politics and the people stresses the connections with York and Scotland. It does not deal with the prophecies relating to scarcity of men.

59 Graunt also mentions the lack of hands for the harvest as a measure of epidemic disease: Observations, ed. Hull, II, p. 391.

6o Anon., The mid-wives just petition (London, 1643), sigs. A2r-[A4r, including marginal reference to Mother Shipton]. My italics.

61 Anon., The coblers last will and testament [London, 166o?]; Henry Bold, Poems lyrique macaronique heroique (London, 1664), pp. 70-1; Henry Bold, Latine songs, with their English: and poems...collected... by Captain William Bold (London, 1685), p. 145.

62 Frances Harris, 'Lady Sophia's visions: Sir Robert Moray, the earl of Lauderdale and the Restoration government of Scotland', Seventeenth Century, 24 (2009), pp. 129-55, esp. pp. 132-4. On Moray, see also R. Kargon, 'John Graunt, Francis Bacon, and the Royal Society: the reception of statistics', Journal of the History of Medicine, 18 (1963), pp. 337-48. 
to argue the case; it was simply something that all men took for granted. We can also see that there were a range of reasons why they might have thought so at that particular place and time. But the examples of Ochino, and the sixteenth-century religious and medical reformer Paracelsus, as well as the work of Peter Biller, suggest that this was a view which men in many different times and places were prone to hold, especially in times of stress. Sommerville suggests that a fresh debate over monogamy, the sex ratio, and what was 'natural' began in the Renaissance. The prescriptions of Christianity, however defined, were obviously fundamental, but so were the societies and beliefs of antiquity. Certain ideas were very persistent, for example the Hippocratic notion that couples living in luxury were more likely to produce female children, or Aristotle's view that very young or old women were similarly prone to give birth to girls. Any defective union or society, it seemed, was likely to have as one of its results an overplus of females, a view which takes us back to Ochinus's pithy comment about the preference for boys. This generalization could be interpreted as including all human societies after the Fall, or as a defect of Nature in an ageing world. In a discussion of how to bring forth more male children, the authors of The compleat midwife's practice (1659) remarked on the declining incidence of twins (one boy and one girl, as previously recorded in history), concluding that:

But after the Earth came to be well increased with people, it hapned, as it appears, that this method and design of Nature was broken off, and now not onely the double Child-bearing is very rare; but a far greater number of women are daily brought forth into the World than men: Whence it is to be gathered, that either Nature is grown weary, or else interrupted in her course of working. ${ }^{63}$

It may be asked why, if men were so prone to believe, under the weight of cultural as well as circumstantial factors, that there was an excess of women, they were so receptive to the strictly numerical findings of Graunt to the contrary. In the first place, men in different contexts did continue to believe that there were more women than men. Secondly, there was an important incentive in being able to see oneself as the nation favoured by God, so that an overplus of women became a defining feature of less fortunate nations. A balanced and stable ratio in Restoration England did not, in the event, preclude an imbalance elsewhere, either in past times or in societies seen as 'other'. Even Graunt, in spite of his references to natural law, states, in relation to his finding that more males were born in London than females, that 'what the causes hereof are, we shall not trouble our selves to conjecture, as in other Cases: only we shall desire, that Travellers would enquire, whether it be the same in other Countries'. Elsewhere, on the same topic of the contrast between London

${ }^{63}$ Miller, John Milton, p. 39; Sommerville, Sex and subjection, p. 161; Biller, Measure of multitude, pp. 98, 104, 399; R. C. et al., The compleat midwife's practice enlarged (London, 1659), pp. $289,290$. 
and the country, he adds that 'it is possible, that in some other places there are more Females born than Males: which, upon this variation of proportion, I again recommend to the examination of the curious'. ${ }^{6} 4$ Thirdly, impressions of there being 'far too many women', as discussed above, might be as strong as ever, but it would be some reassurance to know that, overall, men were not in the minority and might even be better placed than that.

On the evidence presented above, it remains tantalizing that Graunt came up with the ratio of three women to one man. It has not been possible to confirm this 'rule of three' among the published comments of his English contemporaries about the unbalanced sex ratio, and, as mentioned earlier, Petty reported (albeit somewhat later) that the general view was that there were fewer than twice as many women. Various cultural forms of 'trebleness', or what contemporaries called triplicity, can be found close to Graunt, notably his and others' worries about the Trinity, and the three stages of womanhood as mentioned above. However, this is rather too vague. The most likely source may well have been Paracelsus: specifically, a short, accessible text called De inventione artium, which was included in a Latin collected edition of $1603^{-5}$ reprinted in Geneva in $165^{8}$. In this text, likely to have been both available and congenial to Graunt, Paracelsus considers the religious and practical implications of a badly skewed sex ratio (ten women to one man), and decides that it could form no part of the divine order. However, women undoubtedly outnumbered men, partly because God had so ordained the later ages of the world and partly because of the different mortality rates of the two sexes. Paracelsus concludes that it was more likely that there were three women to one man than the other way around. On polygamy, he thought that changing times might require it, as they had done in the past, but that it must conform to divine law. ${ }^{6}$ If Graunt read this tract, it is likely that others did too. ${ }^{66}$ If Paracelsus is the source, Graunt was seeking to undermine not only his account of the sex ratio but also his view of the divine and natural order. This may well be another aspect of how Graunt sought to represent himself in the Restoration period, in contrast to the younger Graunt attracted to radical religious reform. ${ }^{6}$ Possibly lurking behind the reactions of both Paracelsus and Graunt, and indeed of Graunt's contemporaries, were the notorious practices of the Anabaptists, especially as revealed in the siege of Münster in the 153 os.

64 Graunt, Observations, ed. Hull, II, pp. 374, 389 .

65 Miller, John Milton, p. 39; Cairncross, After polygamy was made a sin, p. 27; C. Webster, Paracelsus: medicine, magic and mission at the end of time (New Haven, CT, 2008). I am indebted to Charles Webster for this account of the text somewhat sketchily quoted by Miller and Cairncross, as well as for his judgement that it can safely be attributed to Paracelsus (it is included by Sudhoff among Paracelsian texts of doubtful authorship). Webster dates the text as from before 1531 (personal communication).

66 Note that the discussion in this article is confined to published works in English.

${ }_{7}$ For an acute analysis of ambivalences in Graunt's approach, see Kreager, 'Graunt, John', and idem, 'Death and method'. 
The 'rule of three' seems to occur in some accounts. ${ }^{68}$ At the same time, there is a rationality in Graunt's attitude to gender issues which resembles that of Paracelsus.

It is frustrating that we are unable to reconstruct more precisely the stages of Graunt's religious progression. Aubrey stated that after many years' note-taking of sermons Graunt took to buying and reading 'the best Socinian bookes' and was for several years of that opinion, before at last becoming (and dying) a zealous Roman Catholic. It has been inferred that Graunt turned Catholic before the Fire; Kreager on the other hand is convinced, on the basis of both elements in the Observations and its reception, that his conversion did not take place until the 1670 . Glass points out that by 1672 Petty was telling Graunt that his being a Romanist was 'now universally known'. It is on record that Graunt retained public offices until 1673 , and that he was charged with recusancy in $1674 \cdot{ }^{69}$ Whatever stage Graunt had reached by 1662 , it can be argued, for example, that he wrote against polygamy partly to avoid the charge levelled at Ochino, that by rejecting the Trinity he would end up as equivalent to a Jew or even a Turk. $7^{\circ}$ It seems fair to conclude that, whatever the views of his contemporaries, Graunt was himself more preoccupied with religious issues than with gender. What Graunt places in the foreground is a concern for order and rational belief against a background of religious and political upheaval, as emphasized in different ways by Buck, Endres, and Kreager. ${ }^{71}$ I would suggest in addition that women as a source of unease and disorder need to be built into Graunt's sense of his society. To put it simply, women's bodies were troubling, but, even in a discourse based primarily on the qualitative, the number of bodies may have been as important as the body. Contemporary notions, or fears, about the numerical excess of women need to be included in constructions of the shift towards masculinity located in mid-century. That there were too many women might have been a recurrent idea over long periods, especially in cities, but there were, as we have seen, reasons for this presumption to take on particular intensity in the 164 os and 165 os. Writers such as Swetnam applied a wealth of pejoratives to women - lewd, idle, noisy, forward, and inconstant. To this negative vocabulary we may have to add 'numerous', insofar as men did think that 'half humankind' was in fact in the majority. Early modern people combined the qualitative and the quantitative in a

68 Cairncross, After polygamy was made a sin, pp. $11,27$.

69 Aubrey's Brief lives, pp. 274-5; Graunt, Observations, ed. Hull, I, pp. xxxvii, xlv; Glass, 'John Graunt', pp. 68, 94; Lewin, 'Graunt, John'; Kreager, 'Graunt, John', pp. 162, 163. Kreager finds conclusions consistent with 'Republican' Socinianism in (for example) the second dedication of the Observations.

$7^{\circ}$ [John Clare], The converted Jew (n.p., 163o), esp. pp. 33, 101; Mortimer, Reason and religion, pp. 76,218 .

${ }^{71}$ P. Buck, 'Seventeenth-century political arithmetic: civil strife and vital statistics', Isis, 68 (1977), pp. 67-84; Endres, 'The functions of numerical data'; Kreager, 'Graunt, John'. 
notion of number - 'numberless number' - which was in effect culturally determined.

Finally, what of the link between the issues discussed here, and modern demographical definitions of the 'real'? It is a matter of everyday experience that statistics, among other facts, are ignored if this suits the argument. ${ }^{2}$ Undoubtedly, we must take into account what we estimate the demographical facts of past societies to be, but we need also to consider how contemporaries perceived their situation, how likely it is that their perceptions would be accurate, and what factors were most likely to affect those perceptions. Modern commentary calls this last process 'social proof' and the often dubious results are known, after Norman Mailer, as 'factoids'. For seventeenth-century people, this was not news. At the beginning of the century, Sir Walter Raleigh noted that 'it is not truth but opinion that can travel the world without a passport'. Further towards its end, William Temple noted wryly that 'some of our Maxims are not so certain as they are current in our common Politicks'.73

$7^{2}$ Statistics and their raw materials are, of course, also social products.

73 Raleigh as quoted by Bonar, Theories of population, p. 20; William Temple, Observations upon the United Provinces of the Netherlands (2nd edn, London, 1673), p. 234. See also Francis Bacon's 'idols of the tribe'. 